Int. J. Dev. Biol. 50: 385-392 (2006)

doi: $10.1387 / \mathrm{ijdb} .052021$ as

Original Article

\title{
Comparison of induction during development between Xenopus tropicalis and Xenopus laevis
}

\author{
AYAKO SEDOHARA ${ }^{1}$, KEIKO SUZAWA ${ }^{2}$ and MAKOTO ASASHIMA ${ }^{*, 1,2,3}$ \\ ${ }^{1}$ Department of Life Sciences (Biology), Graduate School of Art and Sciences, ${ }^{2}$ Department of Biological Sciences, Graduate School of \\ Science, University of Tokyo, Tokyo, Japan and ${ }^{3}$ International Cooperative Research Project (ICORP)/Japan Science and Technology \\ Agency (JST), Tokyo, Japan
}

\begin{abstract}
Several in vitro systems exist for the induction of animal caps using growth factors such as activin. In this paper, we compared the competence of activin-treated animal cap cells dissected from the late blastulae of Xenopus tropicalis and Xenopus laevis. The resultant tissue explants from both species differentiated into mesodermal and endodermal tissues in a dosedependent manner. In addition, RT-PCR analysis revealed that organizer and mesoderm markers were expressed in a similar temporal and dose-dependent manner in tissues from both organisms. These results indicate that animal cap cells from Xenopus tropicalis have the same competence in response to activin as those from Xenopus laevis.
\end{abstract}

KEY WORDS: activin, chd, cer, Xbra, tissue differentiation, Xenopus laevis, Xenopus tropicalis

\section{Introduction}

Xenopus laevis has been widely used as an amphibian model in studies of early embryonic development (Ariizumi et al., 2000, Sive et al., 1998). The presumptive ectodermal region of the late blastulae of Xenopus laevisis composed of undifferentiated cells, known as the animal cap. These cells show competency in response to certain growth factors to differentiate into several different cell lineages. Many in vitro inductive systems using animal cap cells have been developed and various cell and tissue types have been induced using animal caps from Xenopus laevis, including heart, pronephros, pancreas, cartilage and eye (Ariizumi et al., 2003, Asashima et al., 2000a, Chan et al., 1999, Furue et al., 2002, Moriya et al., 2000, Myoishi et al., 2004, Osafune et al., 2002, Sedohara etal., 2003). In addition, animal cap assays have been used to investigate mechanisms of cell differentiation by treating the cells with various growth factors and to analyze gene function by injecting with various mRNAs.

Activin $A$ is a member of the transforming growth factor $\beta$ (TGF$\beta$ ) superfamily (Asashima et al., 1990, Smith et al., 1990) and is a strong inducer of mesoderm in animal cap cells. Activin is expressed at the protein level in developing Xenopus laevis embryos (Ariizumi et al., 1991, Fukui et al., 1993, Fukui et al., 1994, Smith et al., 1991). Activin can interact with specific receptors to activate the expression of genes, including Xbrachyury (Xbra), chordin (chd) and cerberus (cer) through the smad2/4 intracellular signaling pathway (Attisano and Wrana, 1998, Bourillot etal., 2002, Bouwmeester etal., 1996, Hill, 2001, Miyazono etal., 2000, Sasai et al., 1994, Smith, 1993, Smith et al., 1991). Treatment with activin induces animal cap cells to differentiate into specific tissues via the expression of tissue-specific genes in a tightly controlled temporal and dose-dependent manner (Ariizum et al., 1991, Green et al., 1992, Gurdon et al., 1999, Smith, 1993, Smith et al., 1991).

There have been many developmental studies of morphogen gradients and axes patterning (Bourillot et al., 2002, Dubrulle et al., 2001, Dyson and Gurdon, 1998, Fujii et al., 2002, Gamse and Sive, 2000, Gamse and Sive, 2001, Green et al., 1997, Green et al., 1992, Gurdon etal., 1996, Gurdon etal., 1999, Ninomiya etal., 2004, Tabata and Takei, 2004). Morphogen gradients were thought to regulate the positioning of cells in a developing embryo, as well as controlling gene expression and tissue-specific differentiation. Traditionally, activin A (human recombinant activin A) treatment of animal caps from amphibian embryos such as Xenopus laeviswere used in this research (Ariizumi and Asashima, 1995, Ariizumi et al., 1991, Asashima et al., 2000b, Green et al., 1997, Green et al., 1992, Gurdon et al., 1996, Gurdon etal., 1999, McDowell et al., 1997, Ryan et al., 2000). At low concentrations of activin, ventral mesoderm tissues such as coelomic epidermis and blood cells were induced in the animal cap explants. At moderate doses of activin, the animal cap cells differentiated into

Abbreviations used in this paper: RT-PCR, reverse transcriptase polymerase chain reaction; $\mathrm{SS}$, Steinberg's solution; WE, whole embryo.

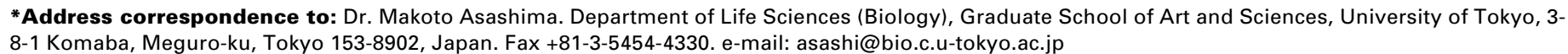

$0214-6282 / 2006 / \$ 25.00$

(c) UBC Press

Printed in Spain

www.intjdevbiol.com 


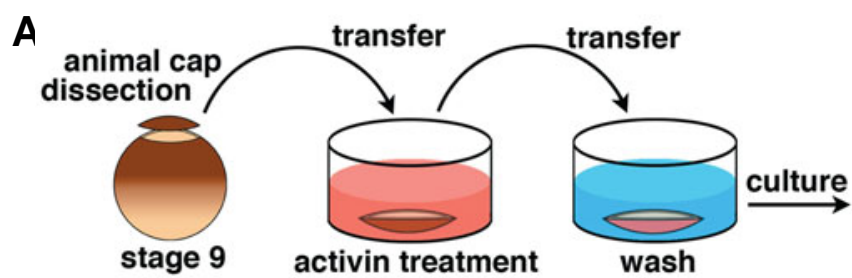

X. laevis
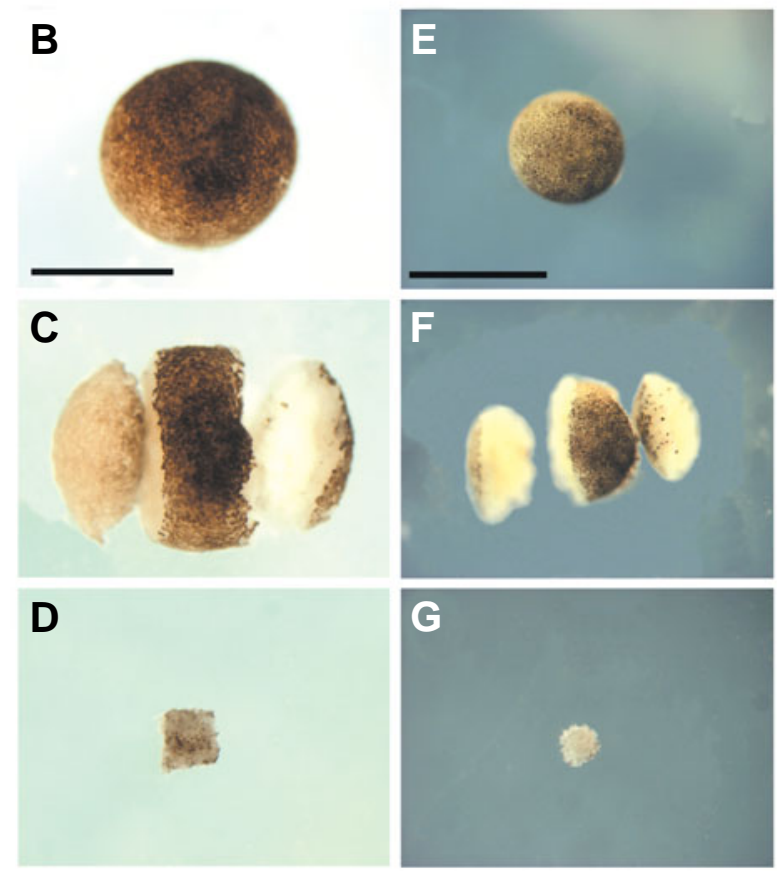

dorsal mesoderm such as muscle. At high doses of activin, axial mesoderm tissues, such as notochord and endodermal cells were induced in the animal cap explants (Ariizumi et al., 1991). In addition, the animal cap cells treated with a high dose of activin could be induced to form head structures in conjugation and transplantation experiments, indicating that the animal cap cells treated with high doses of activin act as the head organizer (Ariizumi and Asashima, 1995, Ninomiya et al., 1999, Sedohara et al., 2002).

Xenopus laevis is an allotetraploid-derived species. For this reason, it has been hard to investigate the function of genes in
Fig. 1. Schematic diagrams of animal cap assay using Xenopus tropicalis and Xenopus laevis. (A) Schematic diagrams of animal cap assay. Animal caps were dissected from late blastulae (stage 9). The animal cap explants were treated with various doses of activin for 1 hour at $20^{\circ} \mathrm{C}$. The activin-treated animal caps were washed three times and cultured in Steinberg solution (SS) containing 0.1\% BSA. (B-G) Method of animal cap dissection from late blastulae of Xenopus laevis (B-D) and Xenopus tropicalis $(E-F)$. (B,E) External views of late blastulae embryo of Xenopus laevis (B) and Xenopus tropicalis (E). (C,F) Removal of bilateral side of embryo. (D,G) Animal cap cells were dissected from late blastulae. The animal cap explant contained $445 \pm 14.0$ (Xenopus laevis) or 448 \pm 18.5 (Xenopus tropicalis) cells. ac; animal cap. Scale bar in $B$ and $E$ indicates $1 \mathrm{~mm}$.

early development using a conventional genetic approach, such as gene-knockout experiments. Xenopus tropicalis, a related species of Xenopus laevis is now also used as a model species in developmental biology studies (Amaya et al., 1998, Song et al., 2003), because Xenopus tropicalis is the diploid species and therefore more amenable to genetic studies (Smith et al., 1991). The genome of Xenopus tropicalis was sequenced recently to construct a genetic linkage map (Kochan et al., 2003). Previous studies have compared the developmental processes in Xenopus laevis and Xenopus tropicalis (Khokha et al., 2002, Sargent and Mohun, 2005, Shook et al., 2004). Fortunately, the same methods established to investigate early development in Xenopus laevis, including mRNA injection, whole-mount in situhybridization and transplantation can also be used in the study of Xenopus tropicalis development (Khokha et al., 2002, Offield et al., 2000). In addition, many of the genes involved in early development in Xenopus laevis are expressed in the same regions and have the same functions in Xenopus tropicalis (D'Souza et al., 2003, Fisher et al., 2003, Fletcher et al., 2004, Haramoto etal., 2004, Knochel etal., 2001, Sekizaki et al., 2004). However, there is little known about the competency of animal caps from Xenopus tropicalis in response to activin treatment. In this study, we compared competence in activin-treated animal cap cells dissected from late blastulae of Xenopus tropicalis and Xenopus laevis.

\section{Results}

\section{Animal cap assay using late blastulae of Xenopus tropicalis}

Schematic diagrams illustrating the animal cap assays performed in this study are shown in Figure 1A. Animal caps were dissected from late blastulae (stage 9). These animal cap ex-

TABLE 1

PCR PRIMER PAIRS

\begin{tabular}{|c|c|c|c|c|c|c|c|}
\hline \multicolumn{4}{|c|}{ Xenopus laevis } & \multicolumn{4}{|c|}{ Xenopus tropicalis } \\
\hline PCR primer pair & Reference & Sequence & $\begin{array}{c}\text { Annealing } \\
\text { temp. } \\
\left({ }^{\circ} \mathrm{C}\right)\end{array}$ & PCR primer pair & Reference & Sequence & $\begin{array}{c}\text { Annealing } \\
\text { temp. } \\
\left({ }^{\circ} \mathrm{C}\right)\end{array}$ \\
\hline Xbra & Sun et al., 1999 & $\begin{array}{l}\mathrm{F}: \text { ttctgaaggtgagcatgtcg } \\
\mathrm{R}: \text { gtttgactttgctaaaagagacagg }\end{array}$ & 55 & Xbra & New & $\begin{array}{l}F: \text { ccagtatgacgtcacagcac } \\
\text { R: gtgcagaccactcacacctg }\end{array}$ & 55 \\
\hline cerberus & Heasman et al., 2000 & $\begin{array}{l}\mathrm{F}: \text { gcttgcaaaaccttgccctt } \\
\mathrm{R}: \text { ctgatggaacagagatcttg }\end{array}$ & 60 & cerberus & New & $\begin{array}{l}F: \text { tggtgccaagatgttctgga } \\
R: \text { atgagcttcacatgcacatt }\end{array}$ & 55 \\
\hline chordin & XMMR & $\begin{array}{l}\mathrm{F} \text { : aactgccaggactggatggt } \\
\mathrm{R} \text { : ggcaggatttagagttgcttc }\end{array}$ & 55 & chordin & New & $\begin{array}{l}\text { F: gctcagcaggtcacgcatgg } \\
\text { R: gttaggtatgtgcacttgtc }\end{array}$ & 55 \\
\hline ODC & Heasman et al., 2000 & $\begin{array}{l}\text { F: gccattgtgaagactctctccattc } \\
\text { R: ttcgggtgattccttgccac }\end{array}$ & 55 & ODC & Haramoto et al., 2004 & $\begin{array}{l}\mathrm{F}: \text { gcacatgtcaagccagttct } \\
\mathrm{R}: \text { tgcgctcagttctggtactt }\end{array}$ & 55 \\
\hline
\end{tabular}


plants were treated with various doses of activin $(0-100 \mathrm{ng} / \mathrm{ml})$ for 1 hour at $20^{\circ} \mathrm{C}$. The activin-treated animal caps were washed two times to remove activin completely. For analysis of gene expression, the resultant explants were sampled immediately until sibling embryos reach stage 10.5 (early gastrulae) or cultured for 5 hours until sibling embryos reach stage 12 (late gastrulae) after activin treatment at $20^{\circ} \mathrm{C}$. We did activin treatment and culturing animal caps for PCR analysis at same temperature in Xenopus laevis and Xenopus tropicalis $\left(20^{\circ} \mathrm{C}\right)$, because temperature is very critical for signaling pathway. The gastrulation proceeds almost equally between Xenopus tropicalisand Xenopus laevisat $20^{\circ} \mathrm{C}$ (Khokha et al., 2002). For histological analysis, the resultant explants were cultured for 2 days at $25^{\circ} \mathrm{C}$ (Xenopus tropicalis) or 3 days at $20^{\circ} \mathrm{C}$ (Xenopus laevis) until sibling embryos reached stage 40 (Fig. 1A). The method of animal cap dissection is shown in Figure 1B-D (Xenopus laevis) and Figure 1E-G (Xenopus tropicalis). The diameter of late blastula of Xenopus laevis is 1.3$1.4 \mathrm{~mm}$ (Fig. 1B), compared to $0.6-0.8 \mathrm{~mm}$ for the late blastula of
Xenopus tropicalis (Fig. 1E). A chorion was removed from the blastulae of both species by fine forceps under a stereomicroscope. The animal pole of the blastulae was directed towards the top and then a bilateral side of the embryo was removed by tungsten needle (Fig. 1C, 1F). Yolk-rich cells at the vegetal pole of the late blastula were omitted from these embryos. The remainder of the animal cap explant was trimmed down to $0.5 \mathrm{~mm}$ $\times 0.5 \mathrm{~mm}$ (Xenopus laevis) or $0.25 \times 0.25 \mathrm{~mm}$ (Xenopus tropicalis) (Fig. 1D, G). The animal cap explant was composed of $445 \pm 14.0$ or $448 \pm 18.5$ cells in Xenopus laevis or Xenopus tropicalis, respectively. These trimmed animal cap explants were used for all subsequent experiments.

\section{The expression of early marker genes was induced by activin treatment in a dose-dependent manner in animal cap ex- plants of Xenopus tropicalis}

We investigated whether the dose-dependent activin effects observed for Xenopus laevis in previous studies were also
A

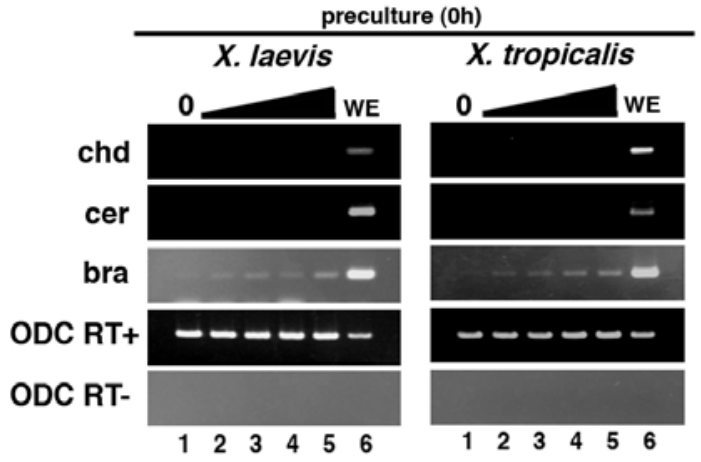

B

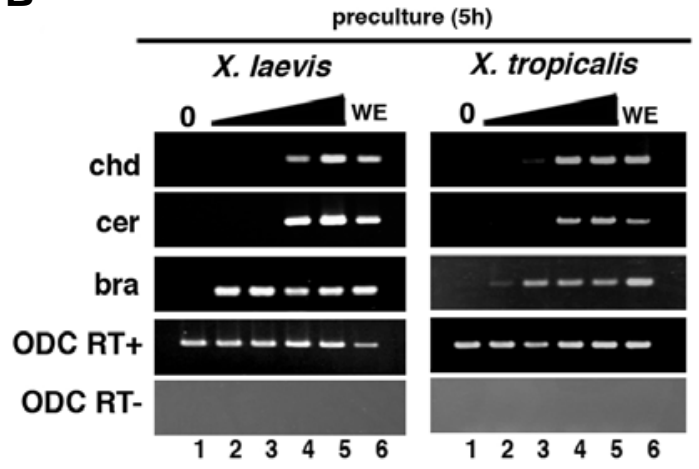

C
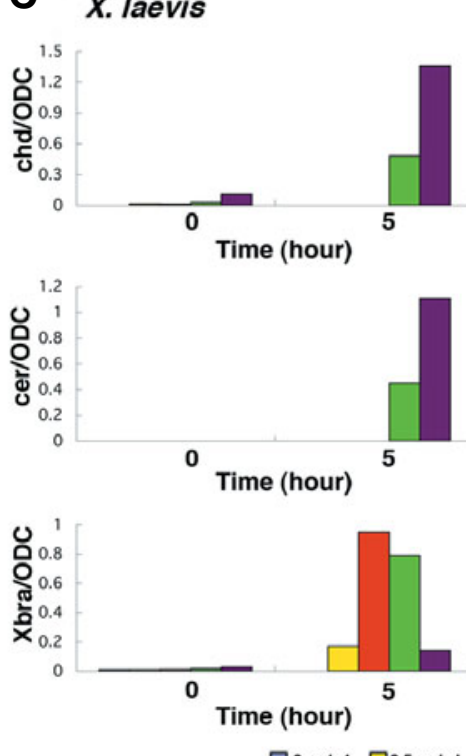

$\square 0 \mathrm{ng} / \mathrm{ml} \quad \square 0.5 \mathrm{ng} / \mathrm{ml} \quad \square 1 \mathrm{ng} / \mathrm{ml} \quad \square 10 \mathrm{ng} / \mathrm{ml} \square 100 \mathrm{ng} / \mathrm{ml}$

Fig. 2. Analysis of gene expression in activin-treated animal cap explants dissected from Xenopus laevis and Xenopus tropicalis. (A,B) RT-PCR analyses of activin-treated animal cap explants. Left panels indicate the results for Xenopus laevis. Right panels indicate the results for Xenopus tropicalis. For cDNA synthesis, total RNA was extracted from 10 or 15 animal caps in Xenopus laevis or Xenopus tropicalis, respectively. This experiment was carried out three times with the same result. (A) RT-PCR analyses of animal cap explants treated with various doses of activin $(0,0.5,1,10,100 \mathrm{ng} / \mathrm{ml})$ for 1 hour at $20^{\circ} \mathrm{C}$ and sampled immediately when sibling embryos reached stage 10.5 . In this condition, the expression of organizer markergenes, such as chd and cer, could not be detected at any doses. The expression of the mesodermal marker gene Xbra was detected at both low and high doses of activin. (B) RT-PCR analyses of animal cap explants treated with various doses of activin $(0,0.5,1,10,100 \mathrm{ng} / \mathrm{ml})$ for 1 hour at $20^{\circ} \mathrm{C}$ and cultured for 5 hours until sibling embryos reached stage 12 at $20^{\circ} \mathrm{C}$. The expression of the organizer genes chd and cer was induced at the high dose of activin treatment (lanes 4,5). The high level of Xbra expression could be detected consecutively at every dose of activin treatment. (C,D) Quantitative analysis of gene expression for chordin, cerberus and Xbrachyury in activin-treated animal caps of Xenopus laevis (C) and Xenopus tropicalis (D) by real-time RT-PCR, relative to ODC expression. RNA samples were derived from animal caps treated with $0,0.5,1,10,100 \mathrm{ng} / \mathrm{ml}$ of activin for 1 hour at $20^{\circ} \mathrm{C}$ and then sampled immediately or 5 hours later at $20^{\circ} \mathrm{C}$. The amount of cer expression was almost the same for the two speciesat at high doses of activin for 5 hours. The expression levels of chd at $10 \mathrm{ng} / \mathrm{ml}$ of activin in Xenopus tropicalis was higher than that observed in Xenopus laevis, although the dose of activin for induction of gene expression was the same. The amount of Xbra expressed in Xenopus laevis was higher than that observed in Xenopus tropicalis, although Xbra expression was observed in $0.5 \mathrm{ng} / \mathrm{m} /$ activin in both species. chd, chordin; cer, cerberus; Xbra, Xbrachyury; WE, whole embryos. 


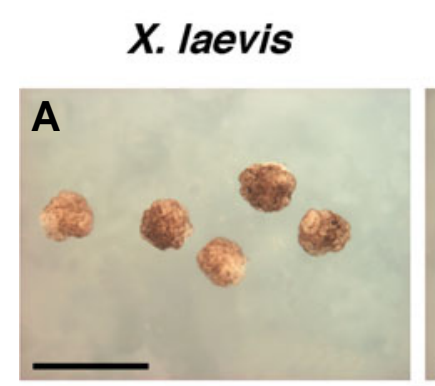

\section{X. tropicalis}
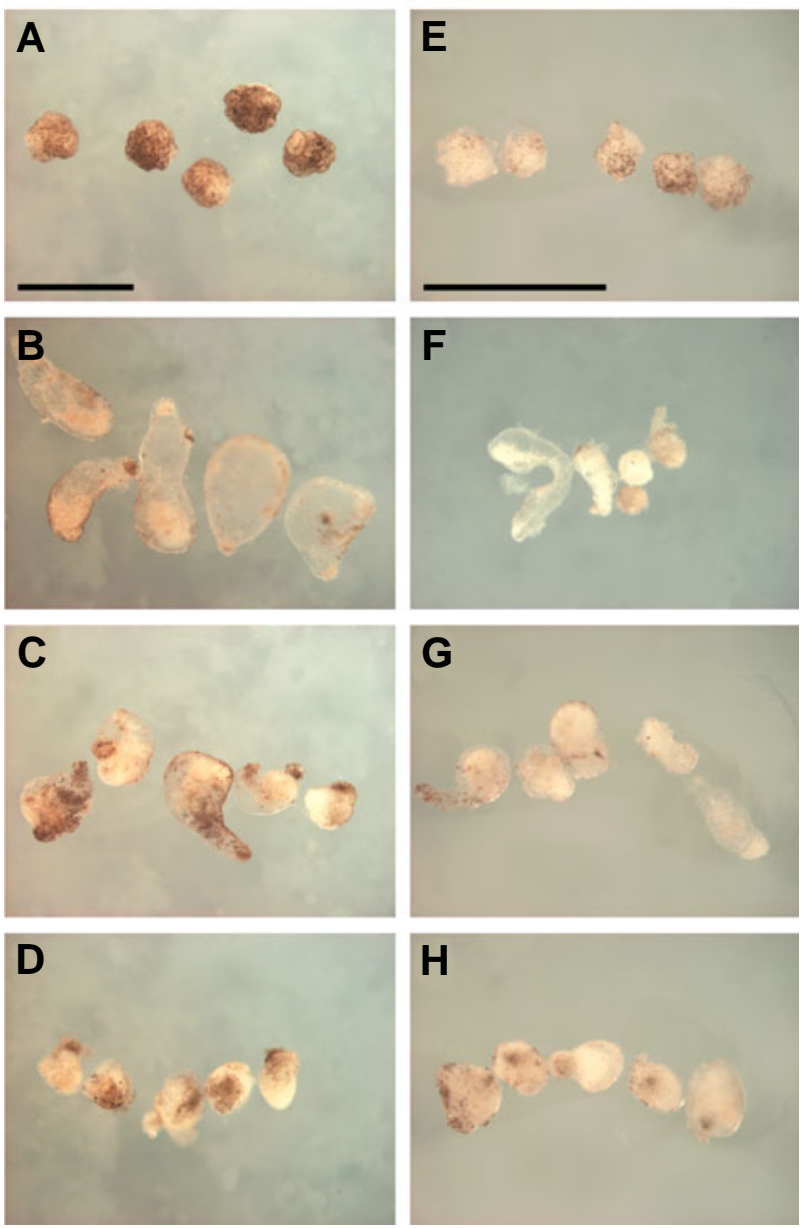

Fig. 3. External views of activin-treated animal cap explants $c$ ultured for 3 days at $20^{\circ} \mathrm{C}$ (Xenopus laevis, left panels) or 2 days at $25^{\circ} \mathrm{C}$ (Xenopus tropicalis, right panels) until sibling embryos reached stage 40. (A,E) Nontreated animal cap explants. (B,F) The animal cap explants were treated with $1 \mathrm{ng} / \mathrm{ml}$ activin. The explants had the appearance of transparent balloons. (C,G) $10 \mathrm{ng} / \mathrm{ml}$ and $\mathbf{( D , H )} 100 \mathrm{ng} / \mathrm{ml}$ activin. At this concentration, the explants became white and round. Note the similarity between explants from blastulae of Xenopus tropicalis treated with graded doses of activin and those from Xenopus laevis treated similarly. Scale bars in (A.E) indicate $1 \mathrm{~mm}$.

apparent in animal cap cells dissected from Xenopus tropicalis. High doses of activin induced the expression of organizer marker genes, such as chordin (chd) and cerberus (cer), whereas lower doses of activin induced the mesodermal marker gene, $\mathrm{n}$ Xbrachyury (Xbra) in animal cap explants from Xenopus laevis (Bouwmeester et al., 1996, Sasai et al., 1994, Smith, 1993, Smith et al., 1991). To do this, we analysed the expression of region-specific marker genes in activin-treated animal cap explants by RT-PCR and compared the gene expression in Xenopus tropicalis quantitatively with that in Xenopus laevis. The animal cap cells were dissected from the late blastulae of Xenopus tropicalis and Xenopus laevis and treated with various doses of activin $(0,0.5,1,10,100 \mathrm{ng} / \mathrm{ml})$ for 1 hour at $20^{\circ} \mathrm{C}$. Non-treated animal cap explants were used as negative controls. The activin-treated animal cap explants were sampled immediately or cultured for 5 hours at $20^{\circ} \mathrm{C}$ until sibling embryos reached stage 12. Total RNA was extracted from the animal caps of both species, as described. ODC was used as an internal control for all experiments. The expression of $c h d$ and $c e r$ (organizer marker genes) could not be detected at any dose of activin in the treated explants sampled immediately; this was the case for both species (Fig. 2A, left and panels indicates results of Xenopus laevis and Xenopus tropicalis, respectively). The mesodermal marker gene, Xbra was expressed slightly at low and high doses $(0.5-100 \mathrm{ng} / \mathrm{ml})$ of activin in explants from Xenopus laevis and Xenopus tropicalis, respectively (Fig. 2A, lanes 2-5). In contrast, in the explants sampled after culturing for 5 hours, the expression of chd and cer was induced only with the high-dose $(10 \mathrm{ng} / \mathrm{ml}, 100 \mathrm{ng} / \mathrm{ml})$ activin treatments (Fig. 2B, lanes 4-5). In contrast, strong expression of $X b r a$ could be detected at every dose $(0.5-100 \mathrm{ng} / \mathrm{ml})$ of activin treatment for both embryo species (Fig. 2B, lanes 2-5). This result indicates that the animal cap cells dissected from the blastulae of Xenopus tropicalis have competency following activin treatment and that the expression of organizer and mesodermal marker genes was induced by activin in a timeand dose-dependent manner.

We next analyzed the gene expression induced by activin treatment quantitatively using real-time PCR analysis. We measured the expression of a range of marker genes, including chd, cerand Xbrain activin-treated animal caps of

TABLE 2

\section{DIFFERENTIATION OF ACTIVIN TREATED ANIMAL CAPS} IN XENOPUS LAEVIS

\begin{tabular}{lcccc}
\hline activin $\mathbf{( n g / m I , ~} \mathbf{~ h )}$ & $\mathbf{0}$ & $\mathbf{1}$ & $\mathbf{1 0}$ & $\mathbf{1 0 0}$ \\
\hline number of experiments & 17 & 14 & 14 & 15 \\
\hline notochord & $0(0)$ & $0(0)$ & $2(14)$ & $3(20)$ \\
muscle & $0(0)$ & $10(71)$ & $14(100)$ & $15(100)$ \\
pronephros & $0(0)$ & $0(0)$ & $3(21)$ & $0(0)$ \\
mesenchyme & $0(0)$ & $14(100)$ & $13(93)$ & $10(67)$ \\
neural tissues & $0(0)$ & $0(0)$ & $10(71)$ & $6(40)$ \\
epidermis & $0(0)$ & $14(100)$ & $14(100)$ & $14(93)$ \\
endodermal cells & $0(0)$ & $0(0)$ & $1(7)$ & $4(27)$ \\
atypical epidermis & $17(100)$ & $0(0)$ & $0(0)$ & $0(0)$ \\
\hline
\end{tabular}

Numbers in brackets indicate the percentage of tissue differentiation respectively.

TABLE 3

DIFFERENTIATION OF ACTIVIN TREATED ANIMAL CAPS IN XENOPUS TROPICALIS

\begin{tabular}{lcccc}
\hline activin $\mathbf{( n g / m I , ~} \mathbf{~} \mathbf{~}$ ) & $\mathbf{0}$ & $\mathbf{1}$ & $\mathbf{1 0}$ & $\mathbf{1 0 0}$ \\
\hline number of experiments & 16 & 26 & 25 & 23 \\
\hline notochord & $0(0)$ & $0(0)$ & $8(32)$ & $7(30)$ \\
muscle & $0(0)$ & $7(27)$ & $24(96)$ & $5(22)$ \\
pronephros & $0(0)$ & $0(0)$ & $0(0)$ & $0(0)$ \\
mesenchyme & $0(0)$ & $17(65)$ & $8(32)$ & $0(0)$ \\
neural tissues & $0(0)$ & $5(19)$ & $17(96)$ & $18(78)$ \\
epidermis & $0(0)$ & $19(73)$ & $24(96)$ & $4(17)$ \\
endodermal cells & $0(0)$ & $0(0)$ & $3(12)$ & $21(91)$ \\
atypical epidermis & $16(100)$ & $14(54)$ & $0(0)$ & $0(0)$ \\
\hline
\end{tabular}

Numbers in brackets indicate the percentage of tissue differentiation respectively. 
Xenopus laevis (Fig. 2C) and Xenopus tropicalis (Fig. 2D), relative to ODC expression. RNA samples were derived from animal caps treated with $0,0.5,1,10,100 \mathrm{ng} / \mathrm{ml}$ of activin for 1 hour and then sampled either immediately or 5 hours later at $20^{\circ} \mathrm{C}$. In animal cap explants sampled immediately after activin treatment, no gene expression was detected in either species. After 5 hours of culturing, the expression of chd and cerwas detected at 10 and $100 \mathrm{ng} /$ $\mathrm{ml}$ of activin and Xbra expression was induced at 0.5-100 $\mathrm{ng} / \mathrm{ml}$ of activin as described above (Fig. 2A, B). The amount of cer expression was similar at high doses of activin (10, $100 \mathrm{ng} / \mathrm{ml}$ ) between the two species. The expression levels of chdat $10 \mathrm{ng} / \mathrm{ml}$ of activin in Xenopus tropicalis was higher than that observed in Xenopus laevis, although the dose of activin that induces the genes expression is the same. In particular, the expression of chd was 5 times higher at 10 $\mathrm{ng} / \mathrm{ml}$ of activin in Xenopus tropicalis than at the same dose in Xenopus laevis. In contrast, the expression level of Xbra at $1-10 \mathrm{ng} / \mathrm{ml}$ of activin in Xenopus laevis was higher than that observed in Xenopus tropicalis and peaked at 1-10 ng/ $\mathrm{ml}$ of activin in Xenopus laevis (there was no peak level of Xbra expression in Xenopus tropicalis). The quantitative analysis by real-time PCR therefore highlighted a difference in the gene expression levels activated by activin treatment between the two species, although the activin needed to induce the gene expression was the same.

\section{Activin-treated animal cap explants from Xenopus tropicalis showed the same morphology as the explants from Xenopus laevis}

To further investigate the competency of animal cap explants from Xenopus tropicalis and Xenopus laevis following activin treatment $(0,1,10,100 \mathrm{ng} / \mathrm{ml})$ for 1 hour, we compared the morphology of respective explants cultured for 3 days at $20^{\circ} \mathrm{C}$ (Xenopus laevis, left panels) or 2 days at $25^{\circ} \mathrm{C}$ (Xenopus tropicalis, right panels) until sibling embryos reached stage 40 as described above. The surface of non-treated explants from both Xenopus laevis and Xenopus tropicalis was quite rough (Fig. 3A, E). The explants treated with $1 \mathrm{ng} / \mathrm{ml}$ of activin had an elongated shape and the appearance of a transparent balloon (Fig. 3B, F). In contrast, treatment with $100 \mathrm{ng} / \mathrm{ml}$ of activin induced the explants to become white, round blocks (Fig. 3D, H), while those treated with $10 \mathrm{ng} / \mathrm{ml}$ of activin assumed a shape that

\section{X. laevis}

A

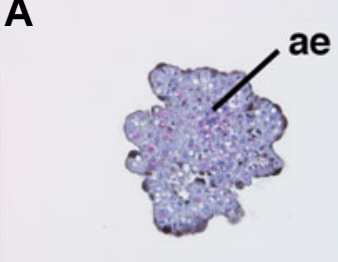

$\longrightarrow$

B

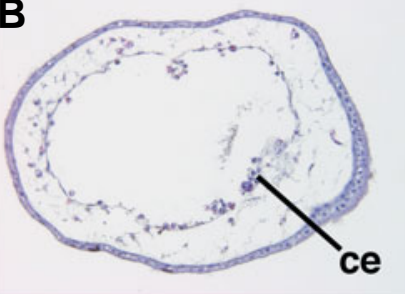

C

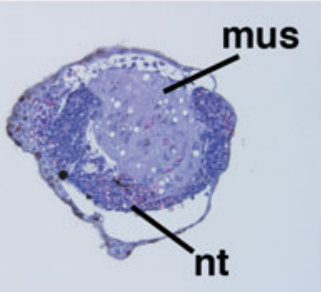

D

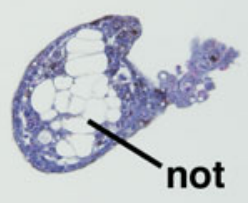

\section{$X$. tropicalis}

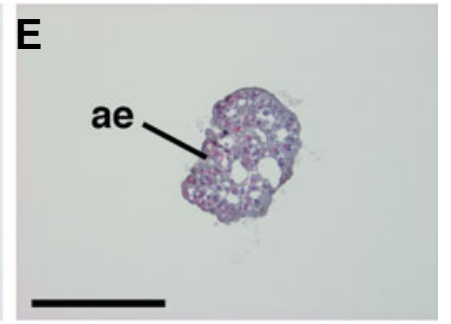

$\mathbf{F}$

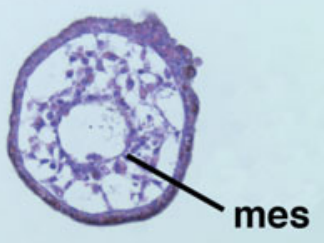

G

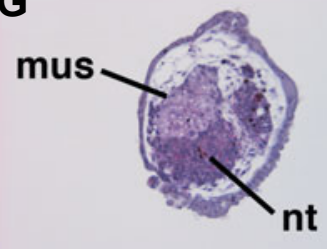

H

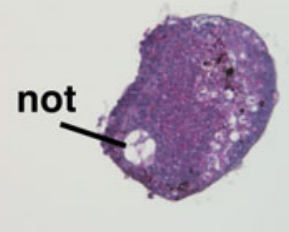

I

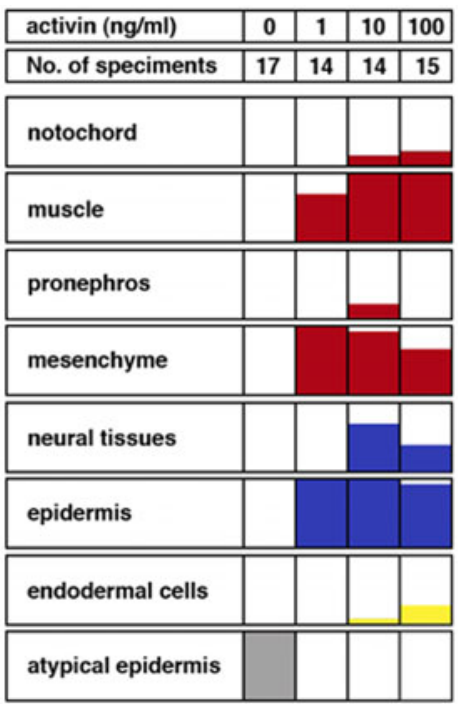

$\mathbf{J}$

\begin{tabular}{|l|l|l|l|l|}
\hline activin (ng/ml) & $\mathbf{0}$ & $\mathbf{1}$ & $\mathbf{1 0}$ & $\mathbf{1 0 0}$ \\
\hline \hline No. of speciments & 16 & 26 & 32 & 23 \\
\hline notochord & & & & \\
\hline \hline muscle & & & & \\
\hline \hline pronephros & & & & \\
\hline \hline mesenchyme & & & & \\
\hline \hline neural tissues & & & & \\
\hline \hline epidermis & & & & \\
\hline \hline endodermal cells & & & & \\
\hline \hline atypical epidermis & & & & \\
\hline
\end{tabular}

Fig. 4. Histological analysis of animal cap explants treated with various doses of activin (A-I, Xenopus laevis; E-J, Xenopus tropicalis ). (A,E) Non-treated animal cap explants. The explants differentiated into atypical epidermis. Mesodermal or endodermal tissues were not obsersved. (B,F) Animal cap explants were treated with $1 \mathrm{ng} / \mathrm{ml}$ activin. The explants contained mesenchyme. (C,G) 10 $\mathrm{ng} / \mathrm{ml}$ activin. Muscle and neural tissues were observed in the explants. (D,H) $100 \mathrm{ng} / \mathrm{m} /$ activin. The axial mesoderm, notochord could be observed at high frequency. In addition, many explants contained an endodermal cell mass. ae, atypical epidermis; ce, coelomic epidermis; mes, mesenchyme; mus, muscle; not, notochord; nt, neural tissues. Scale bars in $(A, E)$ indicate $100 \mu \mathrm{m}$. (I,J) Histogram of the tissue differentiation in the activin-treated animal cap cells of Xenopus tropicalis and Xenopus tropicalis from Tables 2 and 3. Red, mesodermal tissues; Blue, ectodermal tissues; Yellow, endodermal tissue and Gray, atypical epidermis. 
was somewhere between that observed with low and high doses of activin (Fig. 3C, G). This result indicates that the Xenopus tropicalis explants treated with a graded dose of activin had the same gross morphology as those dissected from Xenopus laevis and similarly treated.

\section{Activin-treated animal cap explants from Xenopus tropicalis differentiated into mesodermal and endodermal tissues in a dose-dependent manner}

To investigate what tissue types were differentiated from the treated explants of Xenopus tropicalis, we performed histological analyses of the cultured explants described above. Non-treated animal cap explants from both Xenopus laevis and Xenopus tropicalis differentiated into atypical epidermis (Fig. 4A, E). Mesodermal or endodermal tissues could not be observed in the histological sections. On the other hand, mesenchyme and welldefined epidermis could be observed in the animal cap explants treated with $1 \mathrm{ng} / \mathrm{ml}$ of activin (Fig. 4B, F). Following treatment with $10 \mathrm{ng} / \mathrm{ml}$ of activin, the animal cap explants contained muscle and neural tissues (Fig. 4C, G). The axial mesoderm and notochord could be observed at high frequency in the explants treated with $100 \mathrm{ng} / \mathrm{ml}$ of activin (Fig. 4D, H). In addition, many explants contained an endodermal cell mass (Fig. 4D, H). Tables 2 and 3 summarize the results from the observation of tissue differentiation in the activin-treated animal cap cells of Xenopus tropicalis and Xenopus tropicalis. Histogram representations of the results from these tables is shown in Figure $4 \mathrm{I}$ and $\mathrm{J}$. It is clear from these more quantitative comparisons that there are many differences in the ratios of tissue differentiation between Xenopus laevis and Xenopus tropicalis. The Xenopus tropicalis explants differentiated into muscle much less frequently at the high and low doses of activin compared to Xenopus laevis and differentiated into neural tissues more frequently at all doses. The explants treated with $100 \mathrm{ng} / \mathrm{ml}$ of activin differentiated predominantly into endodermal tissues (91\%) and neural tissues (78\%) in Xenopus tropicalis, while endodermal tissues (93\%), mesenchyme (67\%) and muscle (100\%) were predominantly induced in the explants from Xenopus laevis (Fig. 4I, J).

\section{Discussion}

Here, we aimed to perform animal cap assays from Xenopus tropicalis for histological analysis of in vitro inductive processes as reported in Xenopus laevis. This study demonstrated that animal cap cells dissected from late blastulae of Xenopus tropicalis have the same competence in response to activin as Xenopus laevisanimal caps studied previously (Ariizumi etal., 1991, Green et al., 1997, Green et al., 1992). Organizer and mesoderm marker genes were expressed in the same temporal and dose-dependent pattern. Histological analysis also revealed that activin-treated animal cap explants of Xenopus tropicalis could differentiate into mesodermal and endodermal tissues in a dose-dependent manner. The animal cap cells from Xenopus tropicalis have responsiveness for various inductive signals such as activin and differentiate into various types of tissue in vitro, suggesting that in vitro systems of tissue induction using animal cap assays, as established in Xenopus laevis, may also be used to study Xenopus tropicalis.

This study also compared the responsiveness for activin treat- ment in animal cap cells from Xenopus laevis and Xenopus tropicalis. The qualitative analysis using RT-PCR presented here revealed no difference in the dose of activin required to induce gene expression between Xenopus tropicalisand Xenopus laevis, suggesting that the rate and speed of signal transduction may be regulated by a common system in Xenopus laevis and Xenopus tropicalis. Interestingly, the quantitative analysis using real-time RT-PCR revealed several differences in the levels of individual marker gene expression activated by activin treatment between the two species, indicating that transcriptional regulation might differ between these two species. The expression levels of the organizer marker, cerwas the same in the two species, indicating that the induction of these genes might be conserved during development. Differences in the amounts and peaks of expression of other marker genes ( $c h d$, cerand Xbra) between the two species suggested that there are different mechanisms to define expression levels in a germ layer- (tissue or position) or genespecific manner between Xenopus laevis and Xenopus laevis.

Our experiments also revealed that activin-treated animal cap explants of Xenopus tropicalis can differentiate into mesodermal and endodermal tissues in a dose-dependent manner, as reported previously for Xenopus laevis (Ariizumi et al., 1991, Green etal., 1997, Green etal., 1992). This result indicates that there are common mechanisms of tissue differentiation, which are conserved among species. However, our results also indicated many differences in tissue differentiation between Xenopus laevis and Xenopus tropicalis. This may indicate that the threshold of responsiveness for activin treatment may be more highly defined in animal cap cells from Xenopus tropicalis than in those from Xenopus laevis. The main responsiveness for the activin dose did not differ significantly between the two species, although differences were observed in the ratios of tissues differentiated. It is thought that the cell differentiation is determined by which kind of signal the cell receives during normal development.

Our results support previous developmental comparisons of these two amphibians in demonstrating close similarities (Khokha et al., 2002, Sargent and Mohun, 2005, Shook et al., 2004). For example, many of the genes identified in Xenopus laevisare also expressed in the same regions and elicit homologous functions in Xenopus tropicalis (D'Souza et al., 2003, Fisher et al., 2003, Fletcher et al., 2004, Haramoto et al., 2004, Knochel et al., 2001, Sekizaki et al., 2004). However, many differences also exist in the developmental processes of these two closely related species. The embryos of Xenopus tropicalis develop more rapidly than those of Xenopus laevis and the embryos of Xenopus tropicalis are smaller than those of Xenopus laevis (Amaya et al., 1998, Khokha et al., 2002). In addition, the animal cap explants cultured from Xenopus tropicalis in this study were only half the size of those from Xenopus laevis. Further research is required to clarify whether similar signal transduction mechanisms exist in Xenopus tropicalis to those already defined in Xenopus laevis (Bourillot et al., 2002, Gurdon et al., 1999).

In summary, we described that animal cap cells of Xenopus tropicalis and Xenopus laevis display comparable competence for activin induction. This indicates the likelihood that the same method reported previously in Xenopus laevis can be used for tissue induction in Xenopus tropicalis (Ariizumi and Asashima, 1995, Ariizumi et al., 2003, Asashima et al., 2000a, Chan et al., 1999, Furue et al., 2002, Moriya et al., 2000, Myoishi et al., 2004, 
Osafune etal., 2002, Sedohara etal., 2003). This new information will further advance both tissue induction research and our understanding of the molecular mechanisms of organ differentiation through genetic approaches that are possible by using Xenopus tropicalis.

\section{Materials and Methods}

\section{Xenopus laevis and Xenopus tropicalis embryos}

Xenopus tropicalis embryos were obtained by natural mating, where males and females were primed with 10 units of human chorionic gonadotropin (HCG; Gestron, Denka Seiyaku CO. Kawasaki Japan) at least 12 hours before a booster and incubated at $25^{\circ} \mathrm{C}$. Both males and females were boosted with 100 units of HCG 4 hours before the frogs laid eggs. Xenopus tropicalis fertilized eggs were dejellied with $5 \%$ cysteine hydrochloride (Wako, Japan) (pH 7.8) in Steinberg's solution (SS). Xenopus laevisembryos were obtained as described previousl (Sedohara et al., 2002).

\section{Embryo manipulation and conditioning of activin}

The vitelline membrane was manually removed with fine forceps under a stereomicroscope. All operations were carried out under sterile conditions. Staging of the embryos of Xenopus tropicalis and Xenopus laevis was performed according to Nieuwkoop and Faber (Nieuwkoop and Faber, 1956). Human recombinant activin was dissolved at various concentrations $(0,0.5,1,10,100 \mathrm{ng} / \mathrm{ml})$ in SS containing $0.1 \%$ bovine serum albumin (BSA: Sigma Chemical CO., St Louis, MO, USA) to avoid adsorption of activin to the plastic surfaces.

\section{Analysis of gene expression using RT-PCR and real-time RT-PCR}

Total RNA preparation and RT-PCR were performed as described previously (Sedohara et al., 2002). Total RNA was extracted from 10 or 15 animal cap pieces for each dose of activin for Xenopus laevis and Xenopus tropicalis. Real-time RT-PCR was performed on an ABI PRISM 7700 (Applied Biosystems) using SYBR Green PCR Master Mix (QIAGEN) according to the QuantiTect SYBR Green Kit instructions, as described previously (Abe et al., 2004). The PCR primer pairs are listed in Table 1 (Abe etal., 2004, Haramoto et al., 2004, Heasman etal., 2000, Sun etal., 1999). To ensure that the PCR was in the quantitative linear range, a sample dilution series was performed for each primer pair. Ornithine decarboxylase (ODC) was used as a loading control (Osborne et al., 1991). The relative expression amounts were normalized to ODC.

\section{Histology}

For hematoxylin and eosin staining, the explants were fixed in Bouin's solution $(75 \mathrm{ml}$ saturated picric acid, $25 \mathrm{ml}$ formalin and $5 \mathrm{ml}$ glacial acetic acid) for 3 hours at room temperature. The samples were then dehydrated through a graded ethanol series $(70 \%, 90 \%, 99.5 \%$ and $100 \%)$ for 15 minutes each, infiltrated in xylene for 20 minutes before embedding in paraffin (Histoprep 548). The samples were sectioned serially at $6 \mu \mathrm{m}$ for hematoxylin and eosin staining.

\section{Acknowledgments}

This work was supported in part by a grant-in-aid for Scientific Research from the Ministry of Education, Science, Sports and Culture and Technology, Japan.

\section{References}

ABE, T., FURUE, M., MYOISHI, Y., OKAMOTO, T., KONDOW, A. and ASASHIMA, M. (2004). Activin-like signaling activates notch signaling during mesodermal induction. Int J Dev Bio/48: 327-32.

AMAYA, E., OFFIELD, M.F. and GRAINGER, R.M. (1998). Frog genetics: Xenopus tropicalis jumps into the future. Trends Genet 14: 253-5.
ARIIZUMI, T. and ASASHIMA, M. (1995). Control of the embryonic body plan by activin during amphibian development. Zoolog Sci12: 509-21.

ARIIZUMI, T., KINOSHITA, M., YOKOTA, C., TAKANO, K., FUKUDA, K., MORIYAMA, N., MALACINSKI, G.M. and ASASHIMA, M. (2003). Amphibian in vitro heart induction: A simple and reliable model for the study of vertebrate cardiac development. Int J Dev Bio/47: 405-10.

ARIIZUMI, T., SAWAMURA, K., UCHIYAMA, H. and ASASHIMA, M. (1991). Dose and time-dependent mesoderm induction and outgrowth formation by activin a in xenopus laevis. Int J Dev Bio/35: 407-14.

ARIIZUMI, T., TAKANO, K., ASASHIMA, M. and MALACINSKI, G.M. (2000). Bioassays of inductive interactions in amphibian development. Methods Mol Bio/135: 89-112.

ASASHIMA, M., ARIIZUMI, T. and MALACINSKI, G.M. (2000a). In vitro control of organogenesis and body patterning by activin during early amphibian development. Comp Biochem Physiol B Biochem Mol Biol126: 169-78.

ASASHIMA, M., ARIIZUMI, T., TAKAHASHI, S. and MALACINSKI, G.M. (2000b). Bioassays for studying the role of the peptide growth factor activin in early amphibian embryogenesis. Methods Mol Biol 136: 15-26.

ASASHIMA, M., NAKANO, H., SIMADA, K., KINOSHITA, K., ISHII, K., SHIBAI, H. and UENO, N. (1990). Mesodermal induction during early amphibian development. Roux's Arch. Dev. Biol. 198: 330-35.

ATTISANO, L. and WRANA, J.L. (1998). Mads and smads in TGF beta signalling. Curr Opin Cell Bio/10: 188-94.

BOURILLOT, P.Y., GARRETT, N. and GURDON, J.B. (2002). A changing morphogen gradient is interpreted by continuous transduction flow. Development 129 : 2167-80.

BOUWMEESTER, T., KIM, S., SASAI, Y., LU, B. and DE ROBERTIS, E.M. (1996). Cerberus is a head-inducing secreted factor expressed in the anterior endoderm of spemann's organizer. Nature 382: 595-601.

CHAN, T.C., ARIIZUMI, T. and ASASHIMA, M. (1999). A model system for organ engineering: Transplantation of in vitro induced embryonic kidney. Naturwissenschaften 86: 224-7.

D'SOUZA, A., LEE, M., TAVERNER, N., MASON, J., CARRUTHERS, S., SMITH, J.C., AMAYA, E., PAPALOPULU, N. and ZORN, A.M. (2003). Molecular components of the endoderm specification pathway in xenopus tropicalis. Dev Dyn 226: 118-27.

DUBRULLE, J., MCGREW, M.J. and POURQUIE, O. (2001). Fgf signaling controls somite boundary position and regulates segmentation clock control of spatiotemporal hox gene activation. Cel/106: 219-32.

DYSON, S. and GURDON, J.B. (1998). The interpretation of position in a morphogen gradient as revealed by occupancy of activin receptors. Cel/93: 557-68.

FISHER, M.E., PECK, W., BRANNEY, P.A. and POWNALL, M.E. (2003). Cloning and characterisation of myf5 and myod orthologues in xenopus tropicalis. Biol Cel/95: 555-61.

FLETCHER, R.B., WATSON, A.L. and HARLAND, R.M. (2004). Expression of xenopus tropicalis noggin1 and noggin2 in early development: Two noggin genes in a tetrapod. Gene Expr Patterns 5: 225-30.

FUJII, H., NAGAI, T., SHIRASAWA, H., DOI, J.-Y., YASUI, K., NISHIMATSU, S.I., TAKEDA, H. and SAKAI, M. (2002). Anteroposterior patterning in xenopus embryos: Egg fragment assay system reveals a synergy of dorsalizing and posteriorizing embryonic domains. Dev. Biol. 252: 15-30.

FUKUI, A., NAKAMURA, T., SUGINO, K., TAKIO, K., UCHIYAMA, H., ASASHIMA, M. and SUGINO, H. (1993). Isolation and characterization of xenopus follistatin and activins. Dev Bio/159: 131-9.

FUKUI, A., NAKAMURA, T., UCHIYAMA, H., SUGINO, K., SUGINO, H. and ASASHIMA, M. (1994). Identification of activins $a, a b$ and $b$ and follistatin proteins in xenopus embryos. Dev Bio/163: 279-81.

FURUE, M., MYOISHI, Y., FUKUI, Y., ARIIZUMI, T., OKAMOTO, T. and ASASHIMA, M. (2002). Activin a induces craniofacial cartilage from undifferentiated xenopus ectoderm in vitro. Proc Natl Acad Sci USA 99: 15474-9.

GAMSE, J.T. and SIVE, H. (2000). Vertebrate anteroposterior patterning: The xenopus neurectoderm as a paradigm. BioEssays 22: 976-986.

GAMSE, J.T. and SIVE, H. (2001). Early anteroposterior division of the presumptive neurectoderm in xenopus. Mech. Dev. 104: 21-36.

GREEN, J.B., COOK, T.L., SMITH, J.C. and GRAINGER, R.M. (1997). Anteropos- 
terior neural tissue specification by activin-induced mesoderm. Proc Nat/ Acao Sci USA 94: 8596-601.

GREEN, J.B., NEW, H.V. and SMITH, J.C. (1992). Responses of embryonic xenopus cells to activin and fgf are separated by multiple dose thresholds and correspond to distinct axes of the mesoderm. Cel/71: 731-9.

GURDON, J.B., MITCHELL, A. and RYAN, K. (1996). An experimental system for analyzing response to a morphogen gradient. ProcNat/AcadSciUSA93: 93348.

GURDON, J.B., STANDLEY, H., DYSON, S., BUTLER, K., LANGON, T., RYAN, K., STENNARD, F., SHIMIZU, K. and ZORN, A. (1999). Single cells can sense their position in a morphogen gradient. Development 126: 5309-17.

HARAMOTO, Y., TANEGASHIMA, K., ONUMA, Y., TAKAHASHI, S., SEKIZAKI, H. and ASASHIMA, M. (2004). Xenopus tropicalis nodal-related gene 3 regulates bmp signaling: An essential role for the pro-region. Dev Bio/265: 155-68.

HEASMAN, J., KOFRON, M. and WYLIE, C. (2000). Beta-catenin signaling activity dissected in the early xenopus embryo: A novel antisense approach. Dev Biol 222: $124-34$.

HILL, C.S. (2001). Tgf-beta signalling pathways in early xenopus development. Curr Opin Genet Dev 11: 533-40.

KHOKHA, M.K., CHUNG, C., BUSTAMANTE, E.L., GAW, L.W., TROTT, K.A., YEH, J., LIM, N., LIN, J.C., TAVERNER, N., AMAYA, E. et al. (2002). Techniques and probes for the study of xenopus tropicalis development. Dev Dyn225: 499-510.

KNOCHEL, S., DILLINGER, K., KOSTER, M. and KNOCHEL, W. (2001). Structure and expression of xenopus tropicalis bmp-2 and bmp-4 genes. Mech Dev109: 79-82.

KOCHAN, K.J., WRIGHT, D.A., SCHROEDER, L.J., SHEN, J. and MORIZOT, D.C. (2003). Genetic linkage maps of the west african clawed frog xenopus tropicalis. Dev Dyn 226: 99-102.

MCDOWELL, N., ZORN, A.M., CREASE, D.J. and GURDON, J.B. (1997). Activin has direct long-range signalling activity and can form a concentration gradient by diffusion. Curr Bio/7: 671-81.

MIYAZONO, K., TEN DIJKE, P. and HELDIN, C.H. (2000). TGF-beta signaling by smad proteins. Adv Immuno/75: 115-57.

MORIYA, N., KOMAZAKI, S. and ASASHIMA, M. (2000). In vitro organogenesis of pancreas in xenopus laevis dorsal lips treated with retinoic acid. Dev Growth Differ 42: 175-85.

MYOISHI, Y., FURUE, M., FUKUI, Y., OKAMOTO, T. and ASASHIMA, M. (2004). Induction of tooth and eye by transplantation of activin a-treated, undifferentiated presumptive ectodermal xenopus cells into the abdomen. Int J Dev Bio/48: 1105-12.

NIEUWKOOP, P.D. and FABER, J. (1956). Normal table of xenopus laevis (daudin). North-Holland publishing company, Amsterdam.

NINOMIYA, H., ELINSON, R.P. and WINKLBAUER, R. (2004). Antero-posterior tissue polarity links mesoderm convergent extension to axial patterning. Nature 430: 364-7.

NINOMIYA, H., TAKAHASHI, S., TANEGASHIMA, K., YOKOTA, C. and ASASHIMA, M. (1999). Endoderm differentiation and inductive effect of activin-treated ectoderm in xenopus. Dev Growth Differ 41: 391-400.

OFFIELD, M.F., HIRSCH, N. and GRAINGER, R.M. (2000). The development of xenopus tropicalis transgenic lines and their use in studying lens developmental timing in living embryos. Development 127: 1789-97.

OSAFUNE, K., NISHINAKAMURA, R., KOMAZAKI, S. and ASASHIMA, M. (2002).
In vitro induction of the pronephric duct in xenopus explants. Dev Growth Differ 44: $161-7$.

OSBORNE, H.B., DUVAL, C., GHODA, L., OMILLI, F., BASSEZ, T. and COFFINO, P. (1991). Expression and post-transcriptional regulation of ornithine decarboxylase during early xenopus development. Eur J Biochem 202: 575-81.

RYAN, K., GARRETT, N., BOURILLOT, P., STENNARD, F. and GURDON, J.B. (2000). The xenopus eomesodermin promoter and its concentration-dependent response to activin. Mech Dev 94: 133-46.

SARGENT, M.G. and MOHUN, T.J. (2005). Cryopreservation of sperm of xenopus laevis and xenopus tropicalis. Genesis 41: 41-6.

SASAI, Y., LU, B., STEINBEISSER, H., GEISSERT, D., GONT, L.K. and DE ROBERTIS, E.M. (1994). Xenopus chordin: A novel dorsalizing factor activated by organizer-specific homeobox genes. Cel/79: 779-90.

SEDOHARA, A., FUKUI, A., MICHIUE, T. and ASASHIMA, M. (2002). Role of bmp4 in the inducing ability of the head organizer in xenopus laevis. Zoolog Sci19: 67-80.

SEDOHARA, A., KOMAZAKI, S. and ASASHIMA, M. (2003). In vitro induction and transplantation of eye during early xenopus development. Dev Growth Differ45: 463-71.

SEKIZAKI, H., TAKAHASHI, S., TANEGASHIMA, K., ONUMA, Y., HARAMOTO, Y. and ASASHIMA, M. (2004). Tracing of xenopus tropicalis germ plasm and presumptive primordial germ cells with the xenopus tropicalis daz-like gene. Dev Dyn 229: 367-72.

SHOOK, D.R., MAJER, C. and KELLER, R. (2004). Pattern and morphogenesis of presumptive superficial mesoderm in two closely related species, xenopus laevis and xenopus tropicalis. Dev Bio/270: 163-85.

SIVE, H.L., GRAINGER, R.M. and HARLAND, R.M. (1998). Early development of xenopus laevis: A laboratory manual. Cold Spring Harbor Laboratory Press, Cold Spring Harbor, NY.

SMITH, J.C. (1993). Mesoderm-inducing factors in early vertebrate development. EMBO J12: 4463-70.

SMITH, J.C., PRICE, B.M., GREEN, J.B., WEIGEL, D. and HERRMANN, B.G. (1991). Expression of a xenopus homolog of brachyury $(\mathrm{t})$ is an immediate-early response to mesoderm induction. Cel/67: 79-87.

SMITH, J.C., PRICE, B.M., VAN NIMMEN, K. and HUYLEBROECK, D. (1990). Identification of a potent xenopus mesoderm-inducing factor as a homologue of activin a. Nature 345: 729-31.

SONG, M.O., FORT, D.J., MCLAUGHLIN, D.L., ROGERS, R.L., THOMAS, J.H., BUZZARD, B.O., NOLL, A.M. and MYERS, N.K. (2003). Evaluation of xenopus tropicalis as an alternative test organism for frog embryo teratogenesis assayxenopus (fetax). Drug Chem Toxico/26: 177-89.

SUN, B.I., BUSH, S.M., COLLINS-RACIE, L.A., LAVALLIE, E.R., DIBLASIOSMITH, E.A., WOLFMAN, N.M., MCCOY, J.M. and SIVE, H.L. (1999). Derriere: A tgf-beta family member required for posterior development in xenopus. Development 126: 1467-82.

TABATA, T. and TAKEI, Y. (2004). Morphogens, their identification and regulation. Development 131: 703-12.

Received: June 2005

Reviewed by Referees: August 2005

Modified by Authors and Accepted for Publication: October 2005

Edited by: Makoto Asashima 